\section{Benefit-sharing as a tool of conflict transformation: applying the Inter-SEDE model to the Euphrates and Tigris river basins}

Marwa Daoudy

$\mathrm{I}$ equitable access to water has caused much conflict, especially when water is embedded in larger conflicts of a high-politics nature or where limited economic diversification restricts the range of policy options open to governments. Potential solutions tend to involve agreements on volumetric water allocations rather than focusing on the sharing of more broadly conceived potential mutual benefits. Located in the volatile Middle East, the Euphrates and Tigris river basins are examples of this. Moreover, because this region has one of the highest population growth rates in the world, the potential for conflict is increased.

Three dilemmas and the concept of benefit-sharing

Although not heading for water wars, lack of cooperation does carry security implications and can result in sub-optimal water management with adverse consequences for economic development and usually also for the environment. To mitigate actual and potential conflict actually or ostensibly related to water, states need to overcome a "power and security dilemma" while also delivering economic development. ${ }^{1}$ The dilemma is aggravated inasmuch as in many international river basins, power is asymmetrically distributed. ${ }^{2}$

Over the last decade, views have matured. Rather than aiming at conflict resolution - which implies full elimination or control of an ongoing conflict - some argue for the more modest goal of conflict transformation. ${ }^{3}$ Thus, the discussion has begun to emphasize options for cooperation and the amicable sharing of benefits resulting from professionally managed watersheds. Instead of "securitizing" water viewing water through the lens of national security concerns - this has been referred to as the "de-securitization of water resource management" and opens the way to negotiated agreements between and among states and the consequent sharing of benefits. ${ }^{4}$ The application of the concept of benefit-sharing is the central focus of this article.

Another dilemma in international river basins - in addition to water as a security issue - is that optimal water-usage solutions may not be congruent with the principle of equitable utilization. With spiraling water shortages, optimal solutions should be sought but this usually compromises the desire to achieve usage equity at the same time. Threat perceptions based on historic circumstances occurring outside the water sector then often push the issue of water-related equity in the direction of securitization. For example, from a purely technical point of view it may be more efficient to locate dams in basin headwaters, but against this no guarantee may exist for the equitable distribution of benefits such dams may deliver. Unless specific, feasible, and enforceable guarantees can be constructed and unless the nature of regional politics supports such arrangements, this would render optimal technical solutions politically unsuitable.

A third dilemma relates to global public goods and ecological sustainability. It is well established that unregulated access to common pool resources results in unsustainable use, to the final disadvantage of all..$^{5}$ International watersheds constantly run the risk of lacking coherent regulation, either through the prisoner's dilemma rationale whereby affected parties wish to behave as free riders while hoping that others restrain (or are forced to restrain) their abstraction rates, or simply through the lack of legal harmonization and coordinated policies. The inevitable consequence is the overexploitation of the resource, damaging the ecosystems and the services they provide. This is a particular problem with transboundary waters because upstream parties may overuse the resource and downstream states may be powerless to stop this or be unable to extract appropriate compensation.

Pursued as a policy tool especially at international conferences and workshops, where it appears to be more frequently cited than within academia, the concept of benefit-sharing through international watershed management may help address these dilemmas. The simplest and most useful general framework to date divides benefits from cooperation over a shared river basin into environmental, economic, political, and catalytic categories. ${ }^{6}$ From there, levels of conflict or cooperation are largely determined by the incentives co-riparians face. Indeed, the approach is compellingly simple: if there are sufficient incentives to cooperate, states will do so. Yet we also know that in most cases such a solution remains elusive. This triggers the questions of what joint watershed management benefits exist in the first place and how such benefits may best be shared. Developed by Philips, Daoudy, McCaffrey, Öjendal, and Turton, the Inter-SEDE model first analyzed potential security, economic development, and environmental-related benefits of sharing international river basins for the cases of the Jordan, Kagera, and Mekong river basins. ${ }^{7}$ This article applies the model to the cases of the Euphrates and Tigris river basins. 
The water divide: negotiation and conflict transformation among Turkey, Syria, and Iraq

Along the Euphrates and Tigris rivers, relations between Turkey - home to the rivers' headwaters - and Syria and Iraq are characterized by an upstream-downstream geographic asymmetry. This asymmetry is accented by economic and military advantages that favor the upstream riparian, Turkey (see Figure 1 and Table A1).

Since 1980, Turkey has been working on a mega-development project called the Great Anatolian Project or GAP (Güneydogu Anadolu Projesi), consisting of the construction of 22 dams and 19 hydro-electric power plants on the Euphrates and Tigris rivers. Turkey aims to compensate for its lack of oil resources while developing and stabilizing one of its most underdeveloped regions, southeast Anatolia, where the majority of its Kurdish population is living. To date, 44 percent of the GAP have been achieved; this contrasts to only 12.8 percent of all agricultural projects, but 75.4 and 58 percent, respectively, of its energy and social projects. ${ }^{8}$ Although Turkey considers this to be a domestic enterprise, at the regional level, GAP's impact on downstream countries will be quite significant. According to international experts, the full implementation of GAP will ultimately withdraw a maximum of 70 percent of the Euphrates' natural flow, and about 40 percent of its observed flow. ${ }^{9}$ A combination of upstream projects in Turkey and in Syria will affect the farthest downstream riparian, Iraq, especially harshly. But in light of its high water dependence ratio ( 80 percent of its water resources arise from outside its borders) and the centrality of the Euphrates basin for its overall water supply (65 percent of total water volume), the consequences for Syria are also highly problematic. Considering the 44 percent GAP project completion level, the current issue is less quantitative than qualitative. For example, the GAP master plan does not include proper drainage of the return flows from irrigation, and waters reaching Syria and Iraq are increasingly polluted with pesticides and herbicides.

\section{Bilateral negotiations, unstable agreements, and benefit-exhaustion}

Since 1962, Turkey, Syria, and Iraq have been meeting regularly to discuss water developments in the Euphrates basin. Amid steady conflict, the meetings have resulted in the signing of three bilateral agreements. ${ }^{10} \mathrm{~A}$ first hydro-political crisis erupted in 1974 between Syria and Iraq. A combination of planned upstream extraction in Syria (and Turkey), severe drought, and political tension brought the two countries to the verge of war. Fortunately, in addition to exceptionally high precipitation levels in March 1974, a combined Saudi and Soviet mediation effort prevented the conflict from escalating. ${ }^{11}$ As to Turkey and Iraq, political rapprochement favored trade in oil (the Yumurtalik pipeline) and cooperation on the Kurdish file - through a mutual territorial pursuit agreement - and an interruption of water negotiations with Syria until 1983. Regarding the third bilateral country pair,

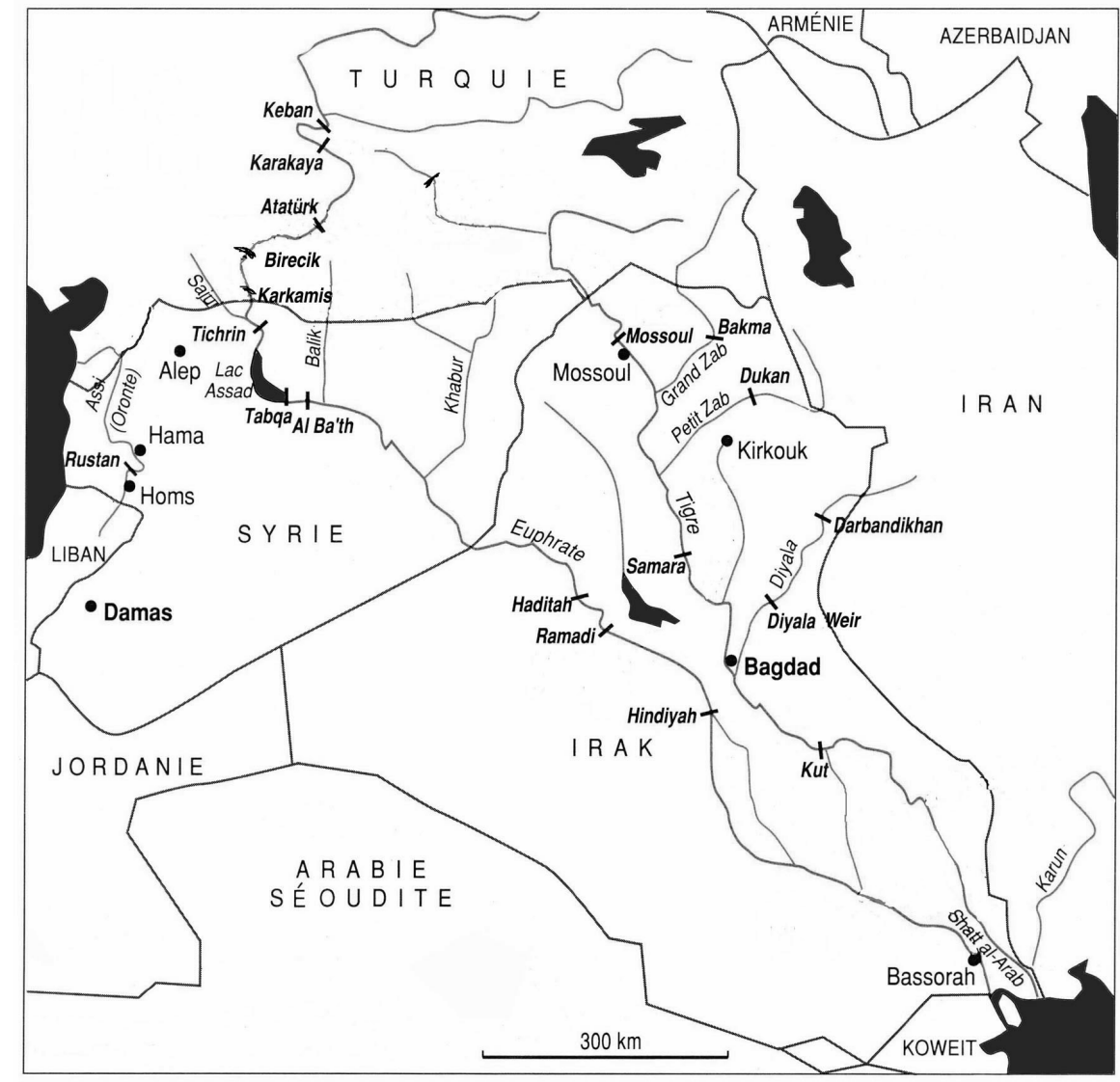

Figure 1: The Euphrates and Tigris rivers, other waterways, and major dams. Source: Daoudy, 2005.

in 1987 Turkey committed within a broad-based economic cooperation protocol to let a minimum volume of $500 \mathrm{~m}^{3} / \mathrm{second}$ of water pass through to Syria. In cases where the monthly flow fell below this level, Turkey agreed to make up the difference during the following month. ${ }^{12}$ Thus, a bilateral water agreement was reached for the first time.

Following the Turko-Syrian agreement, the two downstream countries convened to distribute the remaining waters of the Euphrates, Syria's share amounting to 42 percent and Iraq's to 58 percent of the water volume. Thus, a second bilateral agreement was reached. But when, in early 1990, Turkey undertook a drastic cut of the Euphrates' flow in order to fill its Atatürk dam for a full month, Turkey and Syria were on the brink of war. Instead of pursuing negotiations, the two riparians 
exchanged official notes and mutual complaints through their embassies and by means of official position papers. Only in 2001 were direct water-related meetings renewed. Issuing a Joint Communique on 23 August 2001, followed up with an Implementation Document of 19 June 2002, the two countries' water administrations committed to implementing common research and projects, as well as training programs. ${ }^{13}$ But this third bilateral agreement failed to address volumetric allocations, the pending issue of water quality, and the status of the third co-riparian, Iraq.

In the aftermath of the Iraq war (ongoing since 2003), the resurgence of the United States' dominance in the region, and the rise to power of Iraq's Kurdish minority, Turkey and Syria now have reached an understanding that revolves around their regional strategic interests. Syria, in particular, has agreed to put her water claims aside, giving priority to its wider regional concerns. But core issues of water allocation and polluted return flows from agriculture still remain to be addressed, together with the impact of Turkey's and Syria's upstream projects on downstream Iraq.

Issue-linkage between water-sharing and the upstream country's security concerns over Syria's support of the Kurdish insurgency brought Turkey and Syria to an agreement on minimal water allocation in $1987 .{ }^{14}$ But because agreements of this type tend to be bilateral (ignoring other co-riparians), they are at least somewhat unstable, and benefits that can arise from issue-linkage become exhausted over time. More generally, bilateral agreements cannot be considered to reflect a key principle of customary international water law, namely, equitable utilization. In reality, coriparians compete for available fresh water resources, with little coordination with each other. Basin states thus form potentially unstable geopolitical regions. In the Middle East, this instability is augmented by ethnic and other forms of tension. In contrast, the de-securitization of water issues induced by the recent Turko-Syrian rapprochement has favored the promotion of cooperation.

\section{The Inter-SEDE model: identifying and applying categories of benefits}

The Inter-SEDE model embraces benefit-sharing as its core principle. Because the arenas of security, economic development, and the environment underpin regional development, the model can become the basic framework for conceptualizing benefitsharing in the Euphrates, Tigris, and other river basins. Security is a fundamental issue. By itself it underpins the very existence of human civilization. Insofar as water resource management can provide a platform for regional, national, societal, and human security, this should be understood as a high-order potential benefit. Likewise, economic development drives and is driven by the human cooperative spirit. But both security and economic development are nested within the natural environment. Providing secure access to environmental resources allays threat perceptions and desecuritization can start to gain acceptance. Similarly, humans are part of the environment, sustaining livelihood from it, but also adversely affecting it. Thus, the environment is a sink that translates into thresholds of sustainability. Environmental protection becomes a specific management objective that by itself can start to drive the type of cooperative spirit needed for any form of benefit-sharing.

Table A1 (in the appendix) lists 8 security-related, 9 economic developmentrelated, and 5 environment-related factors that jointly make up the Inter-SEDE model. The table also reports the associated quantitative and qualitative raw data for Iraq, Syria, and Turkey. For selected factors, Table A2 (also in the appendix) illustrates how the raw data are transformed into ranked data. ${ }^{15}$ Table 1 contains the ranked data for all variables. Lower ranks reflect more desirable events or outcomes.

\section{Conflict transformation in the Euphrates and Tigris river basins}

Though not exhaustive, the Inter-SEDE model provides a useful basis to identify existing and future mutual benefits. For example, a comparison of the security-related indicators reveals certain trends (see Table 1). First, military expenditure varies greatly among the co-riparians, being especially high in Iraq as a percentage of GDP. High expenditure indicates a tendency toward greater securitization. Second, the three riparians are ranked as moderately successful in terms of intra-basin cooperation. Moderate cooperation can defuse tendencies toward greater securitization. As noted, cooperation among the co-riparians has been uneven, shifting from a Syria/Iraq coalition against upstream Turkey in the 1980s and 1990s to the Turkey/Syria rapprochement since the early 2000 s. From unarmed conflict to acute episodes of threats of violent military confrontation between Turkey and Syria in 1990, 1993, and 1998 , conflict has persisted in relation to water and security over the Kurdish issue. Water-related agreements among the co-riparians remain of a bilateral nature. A multilateral deal would be preferable. Third, in terms of migration, while Turkey's and Syria's scores are fairly unremarkable, Iraq scores very badly, mainly because large numbers of Iraqi refugees continue to enter Syria and Jordan. But Syria and Turkey also deal with certain migration issues. For example, when the Euphrates and the Atatürk dams started to impound the river's waters in 1974 and 1990, respectively, this led to intrastate displacements for some of the Kurdish populations in southeast Turkey and farmers in northeastern Syria. Fourth, the water dependency ratio reveals drastic asymmetries between upstream Turkey and the downstream riparians, Syria being the most dependent on sources arising from outside its borders. High ratios tend to promote greater securitization. Fifth, water availability/use is also ranked as a security indicator because high availability defuses securitization. With fewer resources at her disposal, Syria scores relatively higher on this criterion than do either Turkey or Iraq.

Summing the security-related ranks, Iraq scores highest (32), followed by Syria (27) and Turkey (21). This suggests that Iraq is most likely to securitize water. Waterrelated problems between and among Turkey, Syria, and Iraq are a source of past and perhaps future regional destabilization. Past conflict has been handled through 
negotiation and bilateral agreements. Future cooperation will be influenced by security-related initiatives and incentives. There are significant concerns on all of the inter and intrastate scales within the two river basins: at the regional level because of continued political tensions among the co-riparians, at the national level because military expenditure could be reduced and channeled toward sustainable development, and at lower geographical scales concerns arise due to competition for resources (including water) by distinct segments of the affected populations.

As regards economic development, Table 1 suggest major differences among the basin states, with Turkey being more developed regarding GDP per capita and literacy rates than either Iraq or Syria. While Turkey's population living below the poverty line is rank-equivalent to Syria's, its infant mortality rate is lower than that of its downstream neighbor. Iraq shows very low GDP per capita, reflecting the continuous humanitarian and economic disaster borne by its population since the early $1990 \mathrm{~s}$. The high summary scores suggest that poverty-related aspects of benefit-generation and sharing are important concerns for the riparian states, especially for Iraq (35) and, somewhat less so, for Syria (24) and Turkey (22). The co-riparians' economies are heavily dependent on the agricultural sector, always the "thirstiest" in terms of the need for water. The sectoral contributions to GDP are particularly revealing, with Turkey and Iraq's agricultural activities contributing relatively less to GDP but demanding more than 70 percent of their available water resources provided at significant subsidies. Syria's agricultural sector contributes the highest share to GDP and receives more than 80 percent of water allocations with high subsidies. It is clear that a regional change in water supply and demand management is inevitable if conflict is to be avoided in the future. This must include a shift from an almost totally agriculturally-based economy toward high value-added use of water in industrial applications. Among the other economic indicators, the per capita water availability data reveal differences between relatively water-rich Turkey and Iraq and waterpoorer Syria. A high level of water availability and use are indicative of the potential for significant economic improvement. The overall average for the average economic indicator across the three countries $(27.0 / 9=3.0)$ is only slightly higher than that for the countries' average security indicator $(26.5 / 8=3.3)$. This suggests that waterrelated poverty alleviation would likely play an important role in the de-securitization of water.

Concerning potential environmental benefits, water pollution problems are of greater significance to the two downstream riparians, and here mostly to Iraq which is farthest downstream. The degradation of water quality is an important concern. In terms of the summary environmental score, Iraq and Syria score the highest of the three co-riparians; this means that they would benefit the most from resolving waterrelated issues. For example, while Turkey's GAP project continues to unfold, return flows from upstream Turkey to Syria will need to be addressed. The sustainable management of the available water resources is a key objective, but it is clear that this has not happened to date. The lack of basin-wide agreements (or of widespread

Table 1: The Inter-SEDE model. Security, economics, and environmentrelated rank indicators in the Euphrates and Tigris river basins

Indicator

Security-related indicators:

Military expenditure ( $\%$ of GDP)

Water availability/use $\left(\mathrm{m}^{3} / \text { person/year }\right)^{*}$

Water dependency ratio $(\%)$ *

History of water-related agreements

Intra-basin cooperation (institutionally)

Geopolitical/governmental stability

Immigration/emigration

Level of regional integration

Totals: security indicators

Economic indicators:

GDP per capita (PPP, US\$)

Population below poverty line

Life expectancy at birth [M/F]

Infant mortality rate

Literacy rate $[\mathrm{M} / \mathrm{F}]$

Energy use (kwh/person/year)

Agriculture as \% of GDP

Industry as \% of GDP

W ater availability/use

Totals: economic indicators
Iraq Syria Turkey Avg.

Environmental indicators:

Importance of flow regime

Water quality index (pollution, salinization) 5

Environmental flows (base flows)

Sustainability of water use

Biodiversity

Totals: environmental indicators

$$
\begin{aligned}
& 3.3 \\
& 3.3 \\
& 3.0 \\
& 2.0 \\
& 3.6 \\
& 3.0 \\
& 4.0 \\
& 26.5
\end{aligned}
$$$$
4.3
$$

* Water availability and water dependency (i.e., the percentage of water in the overall water volume that is generated outside of national borders) are introduced as security and development factors. 
cooperation) constitutes a primary reason for this, but it is also clear that holistic development plans are absent in most cases.

It is also notable that "pure" environmental indicators such as base river flows and biodiversity are generally given short shrift in the region. The relatively higher average for the average environmental indicator $(19.7 / 5=3.9)$ suggests the importance of potential environmental benefits in the Euphrates and Tigris river systems. Biodiversity is generally low and the co-riparians have opted to develop and utilize the water resources to the maximum extent possible, ignoring all requirements for environmental/base flows in rivers. The past and projected upstream withdrawals by Turkey on the Euphrates and Tigris (and to some extent by Syria on the Euphrates) will eventually and markedly reduce the level and quality of the rivers.

\section{Conclusion}

Interactions among the co-riparians have become predominantly cooperative. Yet despite recent declarations regarding the resumption of trilateral talks, the roots of their water conflicts have not been fully acknowledged or addressed. From a conflict transformation perspective, de-securitization of water-related issues requires one to focus on three core variables: interests, power, and rights. The identification of the actors' core interests provides direct and indirect measures of the entanglement of water with security issues. An actor has an intrinsic interest if it values agreement on an issue per se. This is the case for downstream Syria and Iraq. The interest becomes instrumental when placed in relation to major collateral or future advantage. Some actors have an intrinsic interest in delineating a lasting settlement to the hydraulic issue - sometimes involving both the search for water and for food security - while others seek to satisfy wider strategic interests tied to regional security, such as upstream Turkey's interest in increasing its security by agreeing only to minimal transboundary flows. As its GAP project unfolds, questions regarding the ultimate impact on Syria and Iraq's water consumption and use remain unanswered.

The output from an expanded version of the Inter-SEDE model is of particular interest here. Perhaps surprisingly, in terms of the average indicator scores, incentives for environmental cooperation would seem even more important than those in the security and economic fields (scores of 3.9,3.3, and 3.0, respectively). ${ }^{16}$ The potential for spill-over from water cooperation to conflict prevention is important. This is especially so if a heavy securitization dynamic already exists and viable options can nevertheless be found to induce the parties to agree on solutions concerning water availability. In certain transboundary basins, enhanced cooperation on the sharing of water (or the benefits arising from water resources) offers real promise for defusing tensions and reducing broader conflicts. Recent de-securitization trends within the Euphrates and Tigris basins have clearly shifted the focus to economic benefits related to water-sharing. In effect, the economic indicators describe both the degree of poverty and the development potential within each country. Reliance on agriculture and industry measures the potential for water to be utilized in applications with higher value-added, hence contributing to increased economic prosperity. A transition toward industrial uses of water would lead to positive economic development in the predominantly agriculturally-based economies of Turkey, Syria, and Iraq

The expanded model's results reveal important differences between and among the co-riparians. For example, Iraq scores the highest on all three sets of indicators (for an average of 4.0, as compared with 3.2 and 2.8 for Syria and Turkey, respectively), revealing the country's vulnerable downstream position, even as it has undergone and still experiences major human and economic crises. While for all three countries, the average environmental score is the highest, Syria's relatively high average security score, in relation to her average development indicator, highlights it's vulnerable position as the mid-stream riparian, especially in terms of its high ratio of water dependence. Turkey clearly stands apart on some of the economic indicators (reflecting differences in poverty level across the countries). As drivers of potential interstate conflict within the basins, such asymmetries are of very considerable importance, especially if they are coupled to inequitable allocation of water flows or benefits which may arise from the use of shared water resources. It is clear that where a basin hegemon - Turkey in this case - is also an advantaged party in relation to water allocation and economic prosperity, the potential for conflict is significant and the need for equitable readjustment considerable. Mutual bargaining can be made more explicit when incentives are seen as positively affecting the overall pay-off matrix such as for example pipeline transit fees received by Turkey from Iraq or security assurances from Syria on the Kurdish matter.

Durable and peaceful relations between and among riparian states require that benefits are shared, as only then can sustainable and equitable practices be realized. Robust regional and international institutions are important in providing much-needed infrastructure for the promotion and coordination of benefit-sharing. The process of de-securitization can hence be supported by emerging legal rules and norms of state behavior if they can be enforced internally and externally. Any serious analysis of potential benefits should therefore be based on a highly nuanced understanding of fundamental processes at work in the field of hydro-politics and conflict prevention.

\section{Notes}

Marwa Daoudy is Lecturer at the Department of Political Science, Graduate Institute for International Studies, Geneva, Switzerland. She may be reached at daoudy@hei.unige.ch.

\section{Buzan (1991).}

2. See, e.g., Daoudy (2005). 
3. Miller (2005, pp. 26-27).

4. Turton (2003, p. 96).

5. Hardin (1968); Ostrom (1990).

6. Sadoff and Grey (2002).

7. Philips, Daoudy, McCaffrey, Öjendal, and Turton (2006).

8. Republic of Turkey (2005a).

9. Kolars and Mitchell (1991); Kliot (1994).

10. For an extensive analysis of the negotiation process among Turkey, Syria, and Iraq see Daoudy (2005).

\section{Bari (1977); Kienle (1990)}

12. Protocol on Economic Cooperation (1987).

13. Republic of Turkey $(2001,2002)$.

14. Daoudy $(2004 ; 2005)$.

15. Upon request, full details on the transformation for the cases of Iraq, Syria, and Turkey are available from the author. The ranking and banding procedures used in the generation of data for the general Inter-SEDE model are provided in Annex 2 in Philips, et al. (2006, pp. 227-249).

16. Expanding slightly upon the Inter-SEDE model's methodology, one can compute the following average score per state, per indicator, and per state/indicator:

$\begin{array}{llllll} & \text { Iraq } & \text { Syria } & \text { Turkey } & \text { Av. per state } & \text { State av. per indicator } \\ \text { Security }(\mathrm{n}=8) & 32 / 8=4.0 & 27 / 8=3.4 & 21 / 8=2.6 & 80 / 3=26.7 & 26.7 / 8=3.3 \\ \text { Economic dev. }(\mathrm{n}=9) & 35 / 9=3.9 & 24 / 9=2.7 & 22 / 9=2.4 & 81 / 3=27.0 & 27.0 / 9=3.0 \\ \text { Environment }(\mathrm{n}=3) & 21 / 5=4.2 & 20 / 5=4.0 & 18 / 5=3.6 & 59 / 3=19.7 & 19.7 / 5=3.9 \\ \text { Av. indicator } & 88 / 22=4.0 & 71 / 22=3.2 & 61 / 22=2.8\end{array}$

Av. indicator $\quad 88 / 22=4.0 \quad 71 / 22=3.2 \quad 61 / 22=2.8$

where $n$ refers to the number of indicators in each category.

List of references

Bari, Z. 1977. "The Syrian-Iraqi Dispute over the Euphrates Waters.” International Studies, Vol. 16, No. 2, pp. 227-244.
Buzan B. 1991. People, States and Fear: An Agenda for International Security Studies in the Post-Cold War Era. Hertfordshire, UK: Harvester Wheatsheaf.

Daoudy, M. 2005. Le partage des eaux entre la Syrie, la Turquie et l'Irak: négociation, sécurité et asymétrie des pouvoirs. Paris: Editions du CNRS.

Daoudy, M. 2004. "Syria and Turkey in Water Diplomacy (1962-2003)," pp. 319 322,in F. Zereini and W. Jaeschke, eds. Water in the Middle East and North Africa: Resources, Protection and Management. Heidelberg: Springer.

Hardin, G. 1968. "The Tragedy of the Commons." Science Vol. 162, No. 3859 (13 December), pp. 1243-1248.

Kienle, E. 1990. Ba'th v. Ba'th, the Conflict between Syria and Iraq 1968-1989. London and New York: Tauris

Kliot, N. 1994. Water Resources and Conflicts in the Middle East. London: Routledge.

Kolars, J.F. and W.A. Mitchell. 1991. The Euphrates River and the Southeast Anatolia Development Project. Carbondale, IL: Southern Illinois University Press.

Miller, C.E. Miller. 2005. A Glossary of Terms and Concepts in Peace and Conflict Studies. 2nd ed. Addis Ababa: United Nations University for Peace Africa Program.

Ostrom, E.. 1990. Governing the Commons: The Evolution of Institutions for Collective Action. Cambridge: Cambridge University Press

Phillips, D., M. Daoudy, S. McCaffrey, J. Öjendal, and A.R. Turton. 2006 "Transboundary W ater Cooperation as a Tool for Conflict Prevention and Broader Benefit-Sharing." Global Development Studies No. 4, Expert Group on Development Issues (EGDI). Stockholm: Swedish Ministry for Foreign Affairs.

Republic of Turkey. 2005a. "Latest Point Reached in GAP." Southeastern Anatolia Project, Regional Development Administration.

Republic of Turkey. 2005b. Statistical Yearbook. Ankara: Prime Ministry, Turkish Statistical Institute.

Republic of Turkey. 2001. "Joint Communiqué between Republic of Turkey, Prime Ministry, Southeastern Anatolia Project Regional Development Administration (GAP) and Arab Republic of Syria, Ministry of Irrigation, General Organization for Land Development (GOLD), Ankara, 23 August 2001.

Republic of Turkey. 2002. "Implementation Document of Joint Communiqué." Aleppo, 19 June 2002.

Sadoff, C.W. and D. Grey. 2002. "Beyond the River: The Benefits of Cooperation on International Rivers." Water Policy Vol. 4, pp. 389-403.

Syrian Arab Republic. 1987. "Protocol of 1987 on Issues Relating to Economic Cooperation between the Syrian Arab Republic and the Republic of Turkey." 17 July 1987.

Turton, A.R. 2003. "The Political Aspects of Institutional Development in the Water Sector: South Africa and its International River Basins." D.Phil. Thesis. Department of Political Science. University of Pretoria. 
Table A1: Selected indicators for the co-riparians of the Euphrates and Tigris river basins

\begin{tabular}{|c|c|c|c|}
\hline Indicator & Iraq & Syria & Turkey \\
\hline \multicolumn{4}{|l|}{ Security-related indicators: } \\
\hline Military expenditure ( $\%$ of GDP) & 7.5 & 5.9 & 5.3 \\
\hline Water availability/use (m³/person/year) & 3.287 & 1.000 & 3.439 \\
\hline Water dependency ratio (\%) & 53.3 & 803 & 1.0 \\
\hline History of water-related agreements & $\begin{array}{l}\text { few; } \\
\text { bilateral }\end{array}$ & $\begin{array}{l}\text { few; } \\
\text { bilateral }\end{array}$ & $\begin{array}{l}\text { few; } \\
\text { bilateral }\end{array}$ \\
\hline Intra-basin cooperation (institutionally) & mod. & mod. & moderate \\
\hline Geopolitical/governmental stability & low & mod. & moderate \\
\hline Immigration/emigration & massive & mod. & moderate \\
\hline Level of regional integration & very low & low & moderate \\
\hline \multicolumn{4}{|l|}{ Economic indicators: } \\
\hline GDP per capita (PPP, US\$) & 184 & 1,252 & 4,172 \\
\hline Population below poverty line (\%) & nd & 20 & 25.6 \\
\hline Life expectancy at birth $[\mathrm{M} / \mathrm{F}]$ & $59 / 62$ & $70 / 73$ & $68 / 73$ \\
\hline Infant mortality rate $/ 1,000$ births & 83 & 26.3 & 24.6 \\
\hline Literacy rate $[\mathrm{M} / \mathrm{F} \%]$ & $56 / 25$ & $81 / 67$ & $93 / 80$ \\
\hline Energy use (kwh/person/year) & 1,412 & 1,357 & 1,184 \\
\hline Agriculture as $\%$ of GDP & 12.6 & 29.9 & 10.1 \\
\hline Industry as $\%$ of GDP & 8.8 & 25.4 & 24.4 \\
\hline Water availability/use $\left(\mathrm{m}^{3} /\right.$ person/year) & 3.287 & 1.000 & 3.439 \\
\hline \multicolumn{4}{|l|}{ Environmental indicators: } \\
\hline Importance of flow regime & high & moderate & minor \\
\hline Water quality index (pollution, salinization) & $\begin{array}{l}\text { major } \\
\text { problems }\end{array}$ & $\begin{array}{l}\text { moderate } \\
\text { to high }\end{array}$ & $\begin{array}{l}\text { minor } \\
\text { problems }\end{array}$ \\
\hline \multirow[t]{2}{*}{ Environmental flows (base flows) } & not & not & not \\
\hline & addressed & addressed & addressed \\
\hline Sustainability of water use & very low & low & moderate \\
\hline Biodiversity & low & low & moderate \\
\hline \multicolumn{4}{|l|}{ Other indicators: } \\
\hline Gini index & nd & nd & 0.42 \\
\hline Population growth rate (\%/year) & 2.68 & 2.40 & 1.26 \\
\hline Services as $\%$ of GDP & nd & 44.7 & 65.5 \\
\hline $\begin{array}{l}\text { Water management, } \\
\text { incl. sectoral subsidies }\end{array}$ & $\begin{array}{l}\text { subsid. } \\
\text { agric. }\end{array}$ & $\begin{array}{l}\text { subsid. } \\
\text { agric. }\end{array}$ & $\begin{array}{l}\text { subsidized } \\
\text { agriculture }\end{array}$ \\
\hline
\end{tabular}

Note: Data is abstracted from the the FAO Aquastat database for water end environment indicators, the U.N. ESCW A Member Countries 2007 (for Iraq and Syria), the Republic of Turkey's Statistica Yearbook 2005 for socio-economic indicators (2005b), and the CIA World Factbook for military expenditure. nd: No data available.

\section{Table A2: Converting raw to rank data for the Inter-SEDE model}

$\begin{array}{lllll}\text { Country geopolitical/ } & \begin{array}{l}\text { immigration/ } \\ \text { government } \\ \text { emigrability }(\text { band }) * \\ \text { (band)** }\end{array} & \begin{array}{l}\text { energy use } \\ (\text { kwh/person/yr) } \\ \text { (band)*** }\end{array} & \begin{array}{l}\text { agriculture } \\ \text { as of of GD } \\ \text { (band)**** }\end{array} \\ \text { Iraq } & \text { unstable (5) } & \text { massive (5) } & 1,412(2) & 12.6(2) \\ \text { Syria } & \text { moderate (3) } & \text { moderate (2) } & 1,357(2) & 29.9(3) \\ \text { Turkey } & \text { moderate (3) } & \text { moderate (2) } & 1,184(2) & 10.1(2)\end{array}$

* 1: stable; 2: somewhat stable; 3: moderate; 4: low; 5: unstable. High stability reduces a tendency toward greater securitization.

** 1: low; 2: moderate; 3 : high; 4: very high; 5 : massive. High

immigration/emigration enhances a tendency toward greater securitization.

*** $1:>2,500 ; 2: 1,000-2,500 ; 3: 500-1,000 ; 4: 100-500 ; 5:<100$. A high per capita use of energy is indicative of a raised standard of living and suggests poverty-related concerns are less important as drivers.

$* * * * 1:<10 ; 2: 10-20 ; 3: 20-40 ; 4: 40-50 ; 5:>50$. A low dependence on subsistence agriculture is indicative of a raised standard of living and suggests poverty-related concerns are less important as drivers. 